FLEGT License in Indonesia-European Union Cooperation:

Norm Life Cycle Analysis 


\title{
FLEGT License in Indonesia-European Union Cooperation: Norm Life Cycle Analysis
}

\author{
FLEGT License dalam Kerja Sama \\ Indonesia-Uni Eropa: Analisis Norm Life \\ Cycle
}

\author{
Riska Putri Hariyadi \\ Universitas Indonesia
}

\begin{abstract}
ABSTRAK
Artikel ini membahas tentang FLEGT-VPA antara Indonesia dan Uni Eropa setelah mencapai implementasi penuh pada 2016. Kedua pihak menyimpulkan proses akhir dengan penyesuaian V-legal sebagai Lisensi FLEGT untuk produkproduk Kehutanan yang diekspor ke negara anggota Uni Eropa pada November 2016. Hal ini menimbulkan pertanyaan mengenai bagaimana FLEGT License sebagai bagian dari norma internasional dapat digunakan dan diadopsi di Indonesia, meskipun Indonesia telah mengembangkan Sistem Jaminan Legalitas Kayu di bawah SVLK. Menggunakan metodologi content analysis, tulisan ini menelusuri proses adopsi norma dari 2007 hingga 2017. Hasilnya menunjukkan bahwa adaptasi norma melalui penyesuaian V-legal sebagai Lisensi FLEGT dapat dipahami melalui tiga tahapan dari Norm Life Cycle. Lewat pendekatan ini, Uni Eropa mengambil peran sebagai Norm Entrepreneur dan menggunakan FLEGT Action Plan, khususnya skema FLEGT-VPA sebagai organizational platform untuk mempromosikan dan menyosialisasikan normanorma FLEGT ke pelaku bisnis berbasis kehutanan di Indonesia.
\end{abstract}

Kata-kata kunci: FLEGT License; FLEGT-VPA; Norm Life Cycle; SVLK

This paper discusses the FLEGT-VPA between Indonesia and the European Union after completing its full implementation in 2016. The two-party concluded the final process by adjusting V-legal as FLEGT License for Forestry products exported to European Union member states in November 2016. This paper raised a question regarding the process of how the FLEGT License, as a part of the international norm, can be utilized and adopted in Indonesia, given that Indonesia has already developed its Timber Legality Assurances System under SVLK. This paper employs the content analysis method to trace the process of norm adoption from 2007 to 2017. The result shows that the adaptation of norm through the adjustment of V-legal as FLEGT License reflected the three stages of the Norm Life Cycle. According to this approach, European Union is acting as Norm Entrepreneurs and using the FLEGT Action Plan, especially the scheme of FLEGT-VPA, as its organizational platforms to promote and socialize FLEGT norms to forestry-based businesses in Indonesia.

Keywords: FLEGT License; FLEGT-VPA; Norm Life Cycle; SVLK 
FLEGT License in Indonesia-European Union Cooperation:

Norm Life Cycle Analysis

Forest Law Enforcement Government and Trade-Voluntary Partnership Agreement (FLEGT- VPA) atau biasa dikenal sebagai Kemitraan Sukarela-Tindak Penegakan Hukum, Tata Kelola dan Perdagangan Sektor Kehutanan merupakan bagian dari komitmen Uni Eropa dalam memberantas tindakan penebangan kayu liar yang berdampak buruk pada lingkungan. Komitmen ini mulai diwujudkan semenjak FLEGT Action Plan di tahun 2003. Penerapannya dilakukan melalui framework kerja sama bilateral. Negara mitra diharapkan dapat menerapkan tata kelola hutan yang baik serta mengimplementasikan prinsip pengembangan ekonomi yang berkelanjutan (EU FLEGT Facility 2011). Kolaborasi Uni Eropa dengan negara mitra berimplikasi pada reformasi kebijakan pengelolaan kayu termasuk aspek kejelasan asal-usul kayu dan proses penebangan, pengelolaan dalam industri dan distribusi. Framework kerja sama ini secara langsung mendorong transparansi negara-negara produsen kayu pada mekanisme produksi yang berlangsung dari hulu ke hilir sehingga angka kerusakan hutan dapat diturunkan.

Uni Eropa memiliki mitra kerja sama yang tersebar di benua Asia, Afrika dan Amerika. Indonesia merupakan salah satu mitra sukarela yang telah melakukan proses negosiasi dari tahun 2007 dan menandatangani kerangka Voluntary Partnership Agreement di tahun 2013. Selang sembilan tahun dari proses negosiasi awal, Indonesia menjadi negara pertama yang berhasil menerbitkan FLEGT License (Badan Pengkajian dan Pengembangan Perdagangan - Kementerian Perdagangan, 2017). Hal tersebut menandai puncak keberhasilan dari kerja sama bilateral antara kedua pihak karena dengan terbitnya lisensi tersebut, Indonesia dianggap telah melakukan transparansi dan menerapkan sistem legalitas terhadap produk olahan kayu Indonesia yang sesuai dengan standar Uni Eropa. FLEGT License memberikan ruang bagi efektivitas arus perdagangan produk olahan kayu Indonesia ke Uni Eropa otomatis mendapatkan jalur hijau (green lane) tanpa harus melewati mekanisme due diligence atau uji kelayakan (Badan Penelitian, Pengembangan, dan Inovasi - Kementerian Lingkungan Hidup dan Kehutanan 2017).

Uni Eropa merupakan pasar yang signifikan bagi Indonesia karena badan supranasional tersebut merupakan pintu masuk bagi akses pasar yang terdiri dari 27 negara -setelah Inggris resmi keluar. Dengan jumlah negara yang tergabung, skema FLEGTVPA Indonesia secara tidak langsung menerapkan diversifikasi pasar atas produk-produk olahan kayu. Melalui laporan tahunan 
kemitraan Indonesia dan Uni Eropa dalam penerapan FLEGT-VPA di tahun 2013 dan 2014, Indonesia mencetak angka kenaikan nilai ekspor dari 593 juta USD menjadi 645 juta USD (Laporan FLEGTVPA 2015). Pascaproses negosiasi FLEGT-VPA berlangsung, Indonesia terus menunjukkan performa yang positif dalam kenaikan nilai ekspor ke Uni Eropa. Nilai ekspor ke Uni Eropa bertambah positif setelah Indonesia menjadi negara pertama yang memiliki kapasitas untuk menerbitkan FLEGT License. Pada periode satu bulan setelah perilisan FLEGT License pertama di bulan November 2016, Indonesia tercatat mengirimkan 1,7 juta ton produk kayu berlisensi FLEGT dengan nilai 125,8 juta USD (Laporan FLEGT-VPA 2016). Pencapaian tersebut tidak terlepas dari perbaikan sistem legalitas nasional yang terus diperbaiki sesuai dengan standardisasi yang dianjurkan oleh Uni Eropa.

Indonesia memiliki sistem pelacakan yang dibuat untuk memastikan bahwa produk olahan kayu bebas dari aktivitas produksi yang ilegal. Mekanisme dalam negeri tersebut dikenal dengan Sistem Verifikasi Legalitas Kayu (SVLK) yang memiliki tujuan beriringan dengan Timber Legality Assurance System (TLAS). Sistem tersebut diadopsi sebagai mekanisme aktivitas perdagangan kayu global. SVLK mengharuskan setiap kayu untuk memiliki lisensi yang dikenal dengan $V$-legal. Mekanisme ini diharapkan dapat mendorong tercapainya prinsip SVLK yaitu terkait Tata Kelola Kehutanan yang baik (Governance), Keterwakilan (Representatif), Transparansi atau keterbukaan (Credibility) (Departemen Kehutanan SILK t.t). Dokumen legalitas dalam bentuk $V$-legal yang merupakan mekanisme lokal dari TLAS ini kemudian bertransformasi sebagai FLEGT License.

Diskusi akademik terkait FLEGT-VPA antara Indonesia dan Uni Eropa didominasi oleh argumen terkait reformasi dari aspek hukum pengelolaan kayu di level domestik (Lesniewska dan McDermott 2014; Maryudi 2016). Penelitian terkait reformasi dapat dilakukan dengan metode survei yang melibatkan stakeholder atau pemangku kepentingan di negara anggota VPA seperti Indonesia dan Ghana, untuk memetakan perbedaan penerapan prinsip FLEGT Action Plan di masing-masing negara (Wiersum dan Elands 2013). Penerapan reformasi struktural dari rantai produksi produk olahan kayu juga menimbulkan dinamika baru seperti pola relasi kekuasaan yang kemudian kembali dikendalikan oleh industri-industri furnitur berskala besar (Maryudi dan Rodd 2018). Permasalahan lain juga muncul ketika didapatkan temuan yang menunjukkan perilaku menyimpang dari pelaku industri 
kayu akibat kendala-kendala yang menyulitkan dalam pemenuhan aspek legalitas (Acheampong dan Maryudi 2020). Penelitian pada fenomena ini sering kali berpusat dan menjadikan negara mitra sebagai objek utama penelitian, namun demikian terdapat satu penelitian yang mengisi kekosongan literatur terkait peran Uni Eropa di kerangka kerja sama tersebut (Derous dan Verhaeghe 2019).

Pendekatan berbeda yang mewarnai diskusi FLEGT-VPA dari kajian Hubungan Internasional adalah bagaimana framework kerja sama ini dianggap bisa direalisasikan karena dimensi isu yang berorientasi pada motif ekonomi (Schmitz 2016). Reformasi kebijakan dan transparansi dianggap dilakukan demi mendapatkan akses pasar dari Uni Eropa. Senada dengan penelitian Schmitz, Kunkunrat dan Hariyadi (2017) menyajikan penelitian yang memiliki orientasi serupa, namun lebih menekankan pada aspek kepentingan nasional melalui indikator peningkatan nilai ekspor produk olahan kayu Indonesia ke Uni Eropa. Selain menghadirkan pendekatan yang menunjukkan dinamika yang didasari oleh kepentingan ekonomi, Schmitz juga menghadirkan pendekatan analisis konstruktivisme mengenai norm diffusion (2016). Namun, tulisan tersebut tidak menekankan bagaimana norma itu muncul dan kemudian terinternalisasi melalui kebijakan Indonesia terkait fenomena penyetaraan V-legal sebagai Timber Legality Assurance

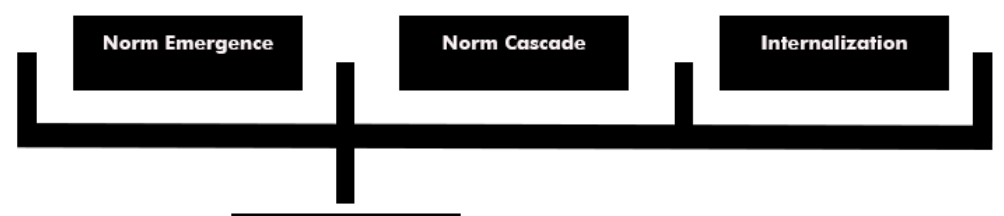

Tipping Point

System di Indonesia dengan FLEGT License.

Pembahasan terkait norm diffusion tidak terlepas dari siapa yang menjadi agen dalam penyebaran norma tersebut serta apa tujuan di balik pembentukan sebuah norma. Uni Eropa dalam fenomena ini menjadi salah satu aktor yang melakukan penyebaran norma terhadap isu penanggulangan pembalakan liar yang terjadi di dunia. Namun, jauh sebelum organisasi internasional menjadi agen dalam menyebarkan norma, sebenarnya mereka merupakan konsumen dari norma-norma yang dikonstruksikan karena 
identitas dari sebuah organisasi tidaklah statis atau tetap (Park 2006). Situasi tersebut menjadikan norma sebagai elemen yang mampu mengubah arah kebijakan politik aktor hubungan internasional (Finnemore dan Sikkink 1998).

Absennya penjelasan terkait proses kemunculan hingga internalisasi norma pada tulisan Schmitz dapat disebabkan oleh periode waktu penelitian yang berhenti sebelum proses skema FLEGT License mulai diimplementasikan secara resmi oleh Indonesia di bulan November 2016. Padahal, kemunculan norma serta proses internalisasi norma kepada sebuah kebijakan memengaruhi identitas baru suatu negara, seperti halnya yang terjadi pada kasus kemitraan sukarela Indonesia dan Uni Eropa. Melihat kurangnya literatur yang menjelaskan proses kemunculan dan internalisasi norma dalam bentuk FLEGT License, penulis bermaksud untuk menyampaikan proses tersebut ke dalam beberapa bagian. Bagian pertama menjelaskan peran Uni Eropa sebagai norm entrepreneur, sementara bagian kedua membahas skema Voluntary Partnership Agreement sebagai mekanisme sosialisasi norma dan internalisasi norma FLEGT License.

\section{Konsep Norm Life Cycle sebagai Kerangka Pemikiran}

Norma menjadi pisau analisis yang hadir melalui pendekatan konstruktivisme. Pendekatan ini dijadikan alternatif dari pendekatan rasionalisme yang mendominasi perdebatan keilmuan Hubungan Internasional di era Perang Dingin. Terdapat perkembangan kerangka konseptual terkait proses adopsi norma internasional oleh negara. Perkembangan tersebut dapat dilihat dalam tulisan Christopher K. Frantz dan Gabriella Pigozzi yang menampilkan empat model dari Norm Life Cycle atau Teori Siklus Hidup Norma (Frantz dan Pigozzi 2018). Empat model yang ditampilkan melalui artikel tersebut di antaranya model pioneer yang dikembangkan oleh Finnemore dan Sikkink di tahun 1998; Savarimuthu dan Cranefield di tahun 2009; Hollander dan Wu di tahun 2011; dan terakhir Mahmoud di tahun 2014. Terlepas dari tahapan-tahapan dalam siklus hidup norma yang lebih kompleks, ketiga model yang dijabarkan oleh Frantz dan Pigozzi dalam artikelnya berakar dari teori yang dicetuskan oleh Finnemore dan Sikkink. Adapun perbedaan signifikan yang menandai keterbaruan tiga model tersebut diperlihatkan melalui aplikasi teori kepada sistem normatif yang bersifat multiagen, kontras dengan versi 
Finnemore dan Sikkink yang secara khusus menjelaskan teori tersebut dalam dimensi hubungan internasional (Frantz dan Pigozzi 2018).

Preferensi dalam memilih model Norm Life Cycle akan tergantung dengan pilihan peneliti dan pemaknaan yang diberikan terhadap fenomena empiris yang dianalisis. Melihat konteks isu penyetaraan $V$-legal dengan FLEGT License yang bermula dari relasi antara Uni Eropa sebagai institusi internasional dan Indonesia sebagai aktor negara, menunjukkan relasi antar aktor dalam dimensi hubungan internasional. Sisi lain yang penting adalah argumen dari Park (2006) bahwa institusi internasional bertindak sebagai norm consumers sebelum berperan sebagai norm diffusers, menunjukkan bahwa diskusi terkait pembuatan norma atau norm creation seharusnya dijelaskan pada kesempatan yang lain karena artikel ini akan lebih berfokus pada poin kemunculan norma dan proses internalisasinya. Oleh karena itu, penelitian ini akan menggunakan teori Norm Life Cycle yang dikembangkan oleh Finnemore dan Sikkink.

Sebelum melangkah lebih jauh dalam memahami Norm Life Cycle, artikel ini akan memberikan pemaknaan terhadap konsep norma sesuai dengan konteks masalah yang diangkat. Norma didefinisikan sebagai landasan nilai yang dikonstruksikan dengan tujuan tertentu. Norma digunakan untuk membuat tuntutan, mendapat dukungan, tindakan membenarkan, tanggung jawab, dan menilai karakter terpuji atau tercela dari suatu tindakan (Winston 2018). Dalam artikelnya, Winston juga menyampaikan bagaimana norma dapat memiliki aspek pembentukan dan pembatasan sehingga struktur konseptual dari norma terdiri atas tiga komponen yaitu, masalah, nilai, dan perilaku (Winston 2018).

\section{Gambar 1.}

Norm Life Cycle 
Finnemore dan Sikkink menjelaskan Norm Life Cycle dalam tiga tahapan (gambar 1). Tahapan-tahapan tersebut di antaranya adalah norm emergence, norm cascade dan internalization (Finnemore dan Sikkink 1998). Norm emergence adalah tahapan siklus hidup norma yang meliputi proses persuasi dari norm entrepreneurs. Finnemore dan Sikkink menekankan bahwa norm entrepreneurs bertindak dalam platform organisasi, seperti organisasi nonpemerintah (Frantz dan Pigozzi 2018). Keberadaan norm entrepreneurs sangat krusial dalam fase norm emergence karena mereka berperan sebagai pemerhati masalah atau pada konteks tertentu berperan sebagai pengonstruksi masalah, dengan menggunakan bahasa penamaan dan penafsiran yang dapat mendramatisir permasalahan yang diangkat. Tahap kedua, adalah norm cascade, perbedaannya dengan tahapan norm emergence dipisahkan oleh tipping point yang menggambarkan peningkatan negara-negara mulai terbuka terhadap norma baru. Norm cascade sendiri identik dengan proses sosialisasi norma internasional yang mengajak norm breakers menjadi norm followers sehingga sosialisasi menjadi mekanisme utama dalam tahapan tersebut. Tahapan terakhir, yaitu internalization atau internalisasi menjelaskan bagaimana seiring proses sosialisasi norma terjadi, debat terkait norma tersebut berakhir dan muncul perilaku penerimaan terhadap norma yang dibangun. Penerimaan ini mendorong konsolidasi pada level lebih dalam sehingga mampu mengubah atau memperbaharui identitas yang dimiliki oleh negara terhadap permasalahan tertentu.

Tabel 1.

Stages of Norms

\begin{tabular}{|l|l|l|l|}
\hline Dimension & $\begin{array}{l}\text { Stage 1 } \\
\text { Norm Emergence }\end{array}$ & $\begin{array}{l}\text { Stage 2 } \\
\text { Norm Cascade }\end{array}$ & $\begin{array}{l}\text { Stage 3 } \\
\text { Internalization }\end{array}$ \\
\hline Actors & $\begin{array}{l}\text { Norm Entrepreneur with } \\
\text { Organizational Platform }\end{array}$ & $\begin{array}{l}\text { State, International } \\
\text { Organization, \& } \\
\text { Networks }\end{array}$ & Law, Profesion \\
\hline Motives & $\begin{array}{l}\text { Altruism, emphaty, } \\
\text { ideational commitment }\end{array}$ & $\begin{array}{l}\text { Legitimacy, } \\
\text { Reputation and } \\
\text { Esteem }\end{array}$ & Conformity \\
\hline $\begin{array}{l}\text { Dominant } \\
\text { Mechanism }\end{array}$ & Persuasion & $\begin{array}{l}\text { Socialization, } \\
\text { Institutionalization, } \\
\text { demonstration }\end{array}$ & $\begin{array}{l}\text { Habit, } \\
\text { Institutionalization }\end{array}$ \\
\hline
\end{tabular}

Sumber: Finnemore dan Sikkink (1998) 
FLEGT License in Indonesia-European Union Cooperation:

Norm Life Cycle Analysis

Kerangka pemikiran yang didasari dari Norm Life Cycle akan menjadi alat bantu dalam menganalisis adopsi FLEGT License pada sistem jaminan legalitas kayu Indonesia. Dalam tulisan yang berjudul International Norm Dynamics and Political Change, Finnemore dan Sikkink menjelaskan lebih lanjut tentang dimensi-dimensi yang memengaruhi siklus hidup norma dengan menjelaskan aktor-aktor penting, motif, serta mekanisme dominan yang berperan penting dalam setiap tahapan Norm Life Cycles. Penulis menggunakan tahapan norma (tabel 1) untuk menginterpretasi fenomena yang dianalisis dengan memetakan aktor-aktor yang terlibat, motif, serta tata cara yang digunakan sehingga adopsi norma illegal logging yang terkandung dalam skema FLEGT License bisa direalisasikan, termasuk proses internalisasi dan penerimaan di masyarakat yang terlibat dalam isu yang didiskusikan pada tulisan ini. Lebih lanjut, pendekatan yang ditawarkan Finnemore dan Sikkink dapat menjelaskan bagaimana identitas baru dapat melekat terhadap aktor hubungan internasional sehingga relevan dalam melihat transformasi Indonesia dari norm breakers menjadi norm followers dalam permasalahan lingkungan hidup, khususnya di sektor pengelolaan sumber daya seiring dengan identitas baru Indonesia sebagai negara yang unggul dalam menerapkan sistem legalitas kayu di dunia.

Dalam proses penelitian ini, penulis menggunakan metode kualitatif content analysis. Metode ini dilakukan dengan menelusuri dan menganalisis dokumen resmi terkait FLEGT License, diskusi artikel ilmiah, serta surat kabar daring yang sesuai dengan fenomena yang diangkat untuk mendapatkan makna dan pola dari teks-teks tersebut (Devi Prasad 2019). Penelusuran akan dibatasi dari periode tahun 2007 sampai dengan 2017. Pembatasan waktu didasari pada tahap awal negosiasi FLEGTVPA dan terbitnya FLEGT License di Indonesia. Guna mencegah tulisan menjadi bersifat terlalu deskriptif pada aspek teknis, penulis bermaksud menggunakan kerangka pemikiran sebagai alat bantu analisis, dengan melengkapi metode penelitian dalam konteks teori Norm Life Cycle dari Finnemore dan Sikkink.

\section{Uni Eropa sebagai Norm Entrepreneurs}

Norm emergence atau fase kemunculan norma merupakan salah satu fase yang signifikan dalam siklus hidup norma. Tahapan 
ini menandai eksistensi aktor yang dikenal sebagai norm entrepreneurs. Dalam kerangka kerja sama yang dibahas, Uni Eropa berperan sebagai norm entrepreneurs semenjak 2003 dengan membangun dan membawa norma penanggulangan pembalakan liar melalui diskursus yang dibangun dengan negaranegara produsen kayu terbesar di dunia. Salah satunya adalah melalui mekanisme kerja sama bilateral sukarela yang dikenal sebagai FLEGT-VPA.

Penentuannormentrepreneurs sebenarnyatidak dapat diputuskan dengan mudah, karena organisasi internasional sempat menjadi norm consumers sebelum mengambil peran sebagai aktor yang menciptakan norma (Park 2006). Argumen tersebut menandai bahwa organisasi internasional bukan satu-satunya subjek yang dapat menciptakan ataupun mempromosikan norma. Premis ini sesuai dengan pendekatan Norm Life Cycle yang digunakan oleh Karim (2010), dengan menampilkan diskursus di publik sebagai titik balik kemunculan Euro-Islam sebagai Transnational Norm. Lebih jauh, tulisan Karim (2010) menyatakan bahwa diskursus norma tersebut berasal dari dua arus utama intelektual yang berperan sebagai Norm Entrepreneurs.

Karena luasnya ruang diskusi untuk menentukan aktor yang berperan dalam membangun diskursus norma penanggulangan pembalakan liar, maka diskusi lebih lanjut terkait hal tersebut dapat dibahas lebih jauh pada artikel lain yang menggunakan rentang waktu penelusuran data lebih luas dari periode 2007 hingga 2017. Identifikasi Uni Eropa sebagai norm entrepreneurs berlandaskan interpretasi dari data-data yang dirilis pada rentang waktu yang telah ditentukan sebagai batas waktu penelitian. Melalui dokumen yang dikumpulkan, Uni Eropa dikategorikan sebagai norm entrepreneurs yang membangun diskursus di ruang publik melalui Forest Law Enforcement Government and Trade (FLEGT) Action Plan di tahun 2003.

Aktualisasi peran diaplikasikan oleh Uni Eropa dengan mendorong diskursus permasalahan lingkungan hidup di sektor kehutanan. Terdapat tiga premis yang menjadi katalis Uni Eropa dalam mengadakan FLEGT Action Plan, di antaranya: (1) kesadaran negara-negara anggota bahwa pembalakan liar memiliki dampak destruktif pada hutan yang ada di dunia dan komunitas yang bergantung dari sumber daya hutan seperti masyarakat adat; (2) pertimbangan terhadap realitas bahwa seluruh lapisan masyarakat Uni Eropa merupakan konsumen terbesar dari 
kayu-kayu yang diterima dari Afrika, Asia, dan Amerika Selatan sehingga masyarakat rentan terlibat dalam penciptaan pasar yang menguntungkan bagi pembalak liar; dan (3) anggota Uni Eropa meyakini dengan membeli produk kepada produsen yang mematuhi hukum nasional, maka mereka ikut serta dalam upaya mengurangi praktik pembalakan liar di dunia (EU FLEGT Facility, t.t.). Melalui tiga faktor di atas, norma FLEGT mewakili fungsi norma yang menilai karakter terpuji ataupun tercela dari suatu tindakan terkait pengelolaan sumber daya hutan (Winston 2018).

Dalam tulisan Finnemore dan Sikkink disampaikan bahwa norm emergence memiliki dimensi motif dari aktor sehingga ia bersedia melakukan proses persuasi. Melalui interpretasi dari premispremis yang mendorong dibentuknya norma FLEGT, Uni Eropa dapat dikategorikan memiliki motif ideational commitment. Jenis motif ini terjadi ketika norm entrepreneurs mempromosikan ide dan norma yang didasari keyakinan pada cita-cita dan nilai-nilai yang terkandung dalam norma-norma, terlepas apakah penerapan norma-norma tidak berpengaruh terhadap kesejahteraan mereka (Finnemore dan Sikkink 1998).

Lebih lanjut, Finnemore dan Sikkink (1998) menyampaikan bahwa kemunculan norma tidak lantas dengan mudah diadopsi oleh publik sehingga norma tidak bisa direalisasikan jika hanya berlandaskan ide dan gagasan. Oleh karena itu, dibutuhkan platform organizational untuk mempromosikan norma. Pada kasus ini, Uni Eropa menggunakan FLEGT-VPA sebagai alat mempromosikan norma. Norm entrepreneurs perlu mendapatkan dukungan negara-bangsa agar dapat melakukan sosialisasi terhadap norma dalam rangka mencapai agenda yang diinginkan. Oleh karena itu, entrepreneurs dapat melakukan beberapa inisiatif termasuk kebijakan untuk mencapai agenda tersebut. Jika diaktualisasikan dalam kasus ini, Uni Eropa melakukan persuasi terhadap keikutsertaan negara produsen seperti Indonesia dengan menutup pasarnya dari produk yang tidak memiliki sertifikasi produk yang bebas praktik pembalakan liar dalam mekanisme $E U$ Timber Regulation.

FLEGT Action Plan membawahi setidaknya tujuh langkah pengamanan agar produk olahan kayu yang masuk ke Uni Eropa merupakan kayu legal. Tujuh langkah pengamanan bermuara pada pola persuasi kepada negara-negara produsen kayu melalui mekanisme bantuan. Beberapa bantuan yang ditawarkan oleh Uni Eropa adalah dengan memberikan bantuan finansial dan teknis, 
misalnya dalam hal pengelolaan dan pengembangan sistem legalitas serta mendorong praktik perdagangan yang bebas dari produk-produk ilegal serta aspek capacity-building lainnya. Dalam konteks FLEGT-VPA antara Indonesia dan Uni Eropa, mekanisme ini dilakukan oleh Uni Eropa dengan memberikan dorongan dalam penerapan sistem jaminan legalitas nasional yang lebih baik lagi.

\section{Skema Voluntary Partnership Agreement (VPA) dan Mekanisme Sosialisasi Norma}

Indonesia dalam kasus ini berperan sebagai critical actor yang signifikan dalam fase tipping point dalam tahapan norm cascade. Di tahun 2011, Indonesia tercatat sebagai pemasok kayu tropis pertama di dunia dengan proporsi kayu ilegal sebesar 40\% (Obidzinski dan Kusters 2015). Kondisi tersebut menandai pentingnya keikutsertaan Indonesia, terlebih karena proporsi tersebut menempatkan Indonesia sebagai norm breakers dalam penanggulangan pembalakan liar. Mekanisme keikutsertaan Indonesia dilakukan dengan motif yang mencerminkan kepentingan nasional dari negara mitra serta kebutuhan untuk memvalidasi status di mata masyarakat internasional. Motif dari aktor-aktor yang terlibat dalam tahapan norm cascade dibagi menjadi tiga kemungkinan: untuk mencari legitimasi, memastikan status dan penghargaan (Finnemore dan Sikkink 1998).

Fase norm cascade diikuti dengan mulai banyaknya negaranegara eksportir kayu dengan sukarela memutuskan bergabung dengan mekanisme Voluntary Partnership Agreement. Mengutip dari The Jakarta Post (2016), Vietnam di tahun 2016 menjadi salah satu negara di kawasan Asia Tenggara yang mengikuti jejak Indonesia dengan menandatangani kesepakatan terkait kewajiban pembangunan sistem jaminan legalitas kayu terhadap produkproduk yang dijual ke Uni Eropa. Tidak hanya Vietnam, Uni Eropa juga berhasil membangun kerja sama dengan negara-negara eksportir kayu yang tersebar di benua Afrika, Asia, dan kawasan Amerika Selatan. Perilaku keikutsertaan negara tanpa tekanan domestik menandai kapasitas norma dalam memengaruhi aktor hubungan internasional.

Menurut Finnemore dan Sikkink (1998), mekanisme sosialisasi dalam politik internasional umumnya dilakukan dengan pujian diplomatik atau kecaman, melalui mekanisme bilateral atau multilateral, serta diperkuat oleh sanksi dan insentif material. 
FLEGT License in Indonesia-European Union Cooperation:

Norm Life Cycle Analysis

FLEGT-VPA dengan skema kerja sama bilateral memberikan ruang untuk pengembangan sistem jaminan legalitas negara mitra untuk terus melakukan perbaikan sehingga mampu berjalan sesuai dengan norma yang terkristalisasi dalam skema ini. Proses sosialisasi meliputi pertukaran ide dan gagasan untuk mencapai agenda penerapan ekonomi berkelanjutan yang ramah lingkungan melalui joint-working group dengan melibatkan seluruh stakeholder yang sudah dimulai dari tahun 2007. Stakeholder dalam mekanisme ini terdiri dari sektor swasta, masyarakat sipil, kementerian terkait, serta pemerintah daerah.

Terjadi capaian signifikan dari FLEGT-VPA antara Indonesia dan Uni Eropa pasca Indonesia meresmikan SVLK sebagai sistem jaminan legalitas kayu nasional (Wiersum dan Elands, 2013). Kebijakan nasional tersebut menunjukkan komitmen pemerintah Indonesia untuk mencapai dua tujuan utama dari FLEGT Action Plan, yaitu perbaikan sistem legalitas kayu negara VPA dan mendorong terbentuknya tata kelola hutan yang baik di negara mitra. Tahapan sosialisasi terjadi selama tahap negosiasi berlangsung antara Indonesia dengan Uni Eropa. Salah satu kerangka kerja yang esensial dalam mekanisme kerja sama antara dua pihak adalah dengan membangun Joint Implementation Committee (JIC) yang dibuat untuk mengakomodasi agenda dapat berjalan berkesesuaian dengan prinsip-prinsip FLEGT.

Sekretariat JIC telah beroperasi semenjak tahun 2014, seiring VPA antara kedua pihak telah memasuki tahap ratifikasi. JIC memiliki kapasitas untuk memastikan bahwa aspek transparansi terkait pelaksanaan FLEGT-VPA dapat diterima dan diakses oleh seluruh stakeholders dengan mendorong wacana terkait mekanisme yang diperlukan untuk mencapai agenda FLEGT Action Plan. Aspek yang esensial dan berada dalam domain peran JIC adalah terkait evaluasi sistem jaminan legalitas kayu yaitu SVLK. Inisiatif dari setiap pertemuan akan berbeda-beda sesuai dari perkembangan yang telah dicapai oleh sistem jaminan legalitas kayu negara mitra.

\section{Internalisasi Norma melalui FLEGT License}

Seiring dengan proses sosialisasi yang dilakukan oleh Uni Eropa kepada Indonesia melalui kerja sama bilateral, terjadi penyebaran norma yang signifikan karena keterlibatan seluruh stakeholder. Hal ini juga didukung dengan prinsip-prinsip FLEGT yang 
dianggap sebagai kebenaran absolut oleh stakeholders sehingga sistem jaminan legalitas kayu sebagai mekanisme berjalan sesuai dengan agenda FLEGT Action Plan. Adopsi prinsip-prinsip FLEGT mentransformasikan sistem jaminan legalitas kayu nasional berupa SVLK dan V-legal dianggap mengimplementasikan prinsip secara menyeluruh dan sesuai standar Uni Eropa. Pencapaian ini ditandai dengan pengakuan kapasitas dokumentasi V-legal setara FLEGT License untuk produk-produk yang akan dikirimkan ke Uni Eropa. Keberhasilannya ditandai dengan penerbitan FLEGT License pertama di bulan November 2016.

Berdasarkan laporan FLEGT-VPA tahun 2015, tercatat kenaikan angka terkait penerapan sistem jaminan legalitas kayu melalui tersertifikasinya lahan dan industri, serta digunakannya dokumen V-legal sebagai syarat untuk ekspor semua produk olahan kayu. Di tahun 2015, tercatat ada 1200 perusahaan dan industri yang berbasis SVLK (Laporan FLEGT-VPA 2015). Angka perusahaan dan industri berbasis hutan dengan SVLK terus naik di tahun 2016 dan 2017 dengan angka 3.498 dan 4.322 (Laporan FLEGTVPA 2016 \& 2017). Di tahun 2016, tepatnya di bulan November, Indonesia telah memiliki kapasitas untuk menerbitkan FLEGT License yang memudahkan akses produk Indonesia di pasar Eropa.

Dalam kurun waktu satu bulan dari bulan November ke Desember, Indonesia mengirim 1,7 ton produk olahan kayu dengan 4.804 lisensi bernilai 125,8 juta USD (Laporan FLEGTVPA 2016). Angka tersebut naik signifikan di tahun 2017 dengan diterbitkannya 36.389 lisensi untuk produk yang dikirim ke Uni Eropa senilai 873 juta USD, yang menandai adanya peningkatan kepatuhan dalam menjamin produk yang bebas dari praktik ilegal. Menurut Finnemore dan Sikkink (1998), internalisasi adalah bentuk ekstrem dari norm cascade, yaitu norma yang muncul dan dibuat akibat permasalahan tertentu menjadi sesuatu yang diterima begitu saja oleh publik (taken for granted).

Diskursus yang dibangun oleh media terkait FLEGT-VPA di Indonesia sering kali mencerminkan keuntungan aspek material berupa peningkatan nilai ekspor. Beberapa media nasional seperti The Jakarta Post dan Republika sering kali mengatributkan FLEGT-VPA dengan proyeksi kenaikan ekspor produk olahan kayu Indonesia ke Uni Eropa. Tulisan yang dirilis The Jakarta Post (2016b) pascafinalisasi implementasi FLEGT-VPA melalui penyetaraan V-legal sebagai FLEGT License memberitakan 


\section{FLEGT License in Indonesia-European Union Cooperation: Norm Life Cycle Analysis}

bagaimana pelaku industri kayu lapis optimis dengan kenaikan jumlah ekspor Uni Eropa dengan memproyeksi kenaikan nilai ekspor sebesar 20\% di tahun 2017.

Diskursus yang dibangun di ruang publik terkait keuntungan material yang tangible ini menjadi salah satu landasan argumen Schmitz (2016) dalam melihat bagaimana difusi norma terkait pengentasan pembalakan liar sangat terikat dengan persepsi para pelaku industri di tanah air yang berlandaskan motif ekonomi. Tulisan ini tidak bermaksud untuk menolak dengan mentah temuan Schmitz dalam artikel yang ia buat di tahun 2016. Terlebih, Bastari (2018) menjabarkan bahwa terdapat dua perspektif dalam melihat difusi norma internasional. Mengutip Acharya, Bastari menjelaskan bahwa norma terbagi menjadi norma yang berkualitas kosmopolitan versi Finnemore dan Sikkink serta norma yang menolak preskripsi-preskripsi dari norma kosmopolitan yang dikenal dengan teori lokalisasi norma (Bastari 2018). Alih-alih menunjukkan kontradiksi terhadap argumen Schmitz, tulisan ini berusaha melengkapi diskusi akademik dengan aspek-aspek yang sebelumnya tidak dicantumkan Schmitz dalam melihat fenomena yang diangkat dengan kacamata difusi norma internasional. Penulis berargumen bahwa norma bukan sesuatu yang bisa secara tiba-tiba terinternalisasi dan harus dipahami melalui sebuah mekanisme yang jelas seperti cara norma itu bisa terbentuk, disosialisasikan, dan kemudian terinternalisasi.

\section{Simpulan}

Fenomena FLEGT-VPA tentang penerapan sistem jaminan legalitas kayu dan pembangunan good forest governance memiliki ruang untuk diskusi akademik yang luas. Dalam lingkup keilmuan hubungan internasional, dan diskursus yang dibangun oleh media yang ditelusuri dalam artikel ini, sering kali fenomena ini didominasi sebagai diskusi yang sarat dengan kepentingan ekonomi negara mitra sebagai upaya mengakses pasar Uni Eropa. Tulisan ini menawarkan pendekatan yang seimbang antara aspek nonmaterial seperti ide dan gagasan, serta aspek material seperti keuntungan ekonomi. Melalui penelusuran studi literatur, masih dibutuhkan pendekatan yang menekankan aspek nonmaterial untuk melihat fenomena FLEGT-VPA karena penelitian terdahulu hanya membahas difusi norma yang terikat dengan persepsi para pelaku industri di tanah air yang berlandaskan motif ekonomi 
tanpa menjelaskan bagaimana proses ide dan gagasan dapat terinternalisasi menjadi kebenaran absolut yang diterima di level domestik.

Dengan melakukan penelusuran dan interpretasi data dari tahun 2007 hingga 2017 yang dapat diakses secara umum, tulisan ini mengidentifikasi proses perubahan identitas Indonesia menjadi norm followers yang berhasil mencapai implementasi penuh FLEGT-VPA dengan penyetaraan V-legal sebagai FLEGT License karena terdapat pertukaran ide dan gagasan yang telah diinisiasi oleh norm entrepreneur. Melalui penggunaan kerangka pemikiran dari teori Norm Life Cycle, analisis dilakukan dengan menginterpretasi dokumen-dokumen relevan yang sesuai dalam tiga tahapan, yaitu norm emergence, norm cascade dan internalization.

Temuan yang ada menjelaskan bahwa penyetaraan V-legal dengan FLEGT License terjadi karena Uni Eropa selaku entrepreneurs membangun platform organizational untuk mempromosikan norma melalui kerja sama bilateral FLEGT-VPA. Skema kerja sama ini kemudian menjadi alat untuk menyosialisasikan norma kepada negara-negara, sekaligus mendorong pengadopsian norma pada level domestik. Adopsi norma pada level domestik merupakan bagian dari internalisasi norma yang membuat ide dan gagasan yang awalnya belum ada menjadi sesuatu yang diterima begitu saja (taken for granted). Masih terdapat banyak ruang diskusi terkait fenomena FLEGT-VPA, khususnya dengan menggunakan perspektif konstruktivis. Beberapa celah penelitian yang dapat dimanfaatkan adalah terkait bagaimana proses ide dan gagasan FLEGT Action Plan dapat diterima oleh seluruh 27 negara anggota Uni Eropa, serta aspek kepatuhan terhadap norma setelah proses internalisasi terjadi di Indonesia.

\section{Referensi}

\section{Jurnal dan Jurnal Daring}

Acheampong, E., dan A. Maryudi, 2020. "Avoiding legality: Timber producers' strategies and motivations under FLEGT in Ghana and Indonesia", Forest Policy and Economics, 111(102047): 1-7. 
FLEGT License in Indonesia-European Union Cooperation: Norm Life Cycle Analysis

Bastari, G.R., 2018. "Budaya Patriarki dan Lokalisasi Norma Pemberantasan Perdagangan Manusia di Indonesia", Global: Jurnal Politik Internasional, 2o(1): 52-69.

Derous, M., dan E. Verhaeghe, 2019. "When P stands for politics. The role of the EU in the VPAs: A research agenda", Forest Policy and Economics, 101: 81-87.

Finnemore, M., dan K. Sikkink, 1998. "International norm dynamics and political change", International Organization, 52(4): 887-917.

Frantz, K., dan G. Pigozzi, 2018. "Modelling Norm Dynamics in Multi-Agent Systems”, Journal of Applied Logics, 5(2): 491-564.

Karim, M.F., 2018. "Proses Munculnya Euro-Islam sebagai Transnational Norms di kalangan Muslim Eropa”, Jurnal Kajian Wilayah, 1(1): 32-58.

Kunkunrat, dan R.P. Hariyadi, 2018. "Kerja Sama FLEGTVPA (Forest Law Enforcement Government and TradeVoluntary Partnership Agreement) Indonesia-Uni Eropa dalam Peningkatan Ekspor Produk Hasil Hutan Indonesia ke Uni Eropa”, TransBorder: International Relation Journal, 1(1): 50-60.

Lesniewska, F., dan C. McDermott, 2014. "FLEGT VPAs: Laying a pathway to sustainability via legality lessons from Ghana and Indonesia", Forest Policy and Economics 48: 16-23.

Maryudi, A., dan M. Rodd, 2018. "Renting legality: How FLEGT is reinforcing power relations in Indonesian furniture production networks", Geoforum, 97: 46-53.

Maryudi, A., 2016. "Choosing timber legality verification as a policy instrument to combat illegal logging in Indonesia", Forest Policy and Economics, 68: 99-104.

Obidzinski, K., dan Kusters, 2015. "Formalizing the Logging Sector in Indonesia: Historical Dynamics and Lessons for Current Policy Initiatives", Society \& Natural Resources, 28(5): 530-542. 
Park, S., 2006. "Theorizing norm diffusion within international organizations", International Politics, 43(3): 342-361.

Prasad, B.D., 2019. "Qualitative content analysis: Why is it still a path less taken?”, Forum Qualitative Sozialforschung/ Forum: Qualitative Social Research, 20(3).

Schmitz, M., 2016. "Strengthening the rule of law in Indonesia: the EU and the combat against illegal logging", Asia Europe Journal, 14(1): 79-93.

Wiersum, K.F., dan B. Elands, 2013. "Opinions on legality principles considered in the FLEGT/VPA policy in Ghana and Indonesia", Forest Policy and Economics, 30: 14-22.

Winston, C., 2018. "Norm structure, diffusion, and evolution: A conceptual approach”, European Journal of International Relations, 24(3): 638-661.

\section{Dokumen Resmi}

Indonesia \& Uni Eropa. 2015. Laporan Tahunan: Penerapan Kesepakatan Kemitraan Sukarela FLEGT Indonesia-Uni Eropa.

Indonesia \& Uni Eropa. 2016. Laporan Tahunan: Penerapan Kesepakatan Kemitraan Sukarela FLEGT Indonesia-Uni Eropa.

Indonesia \& Uni Eropa. 2017. Yearly Report: Implementation of the Indonesia-EU Voluntary Partnership Agreement on Forest Law Enforcement, Governance and Trade.

\section{Artikel Daring}

Badan Penelitian, Pengembangan, dan Inovasi - Kementerian Lingkungan Hidup dan Kehutanan, 2017. "Indonesia Merupakan Negara Pertama dan Satu-Satunya di Dunia Pemegang Lisensi Flegt” [daring]. dalam: https://www. 
FLEGT License in Indonesia-European Union Cooperation: Norm Life Cycle Analysis

forda-mof.org/index.php/berita/post/3565 [Diakses 5 Maret 2020].

Badan Pengkajian dan Pengembangan Perdagangan Kementerian Perdagangan, 2017. "Indonesia Peraih FLEGT License Pertama di Dunia" [daring]. dalam: http:// bppp.kemendag.go.id/media content/2017/08/LeafletIndonesia, Peraih FLEGT License Pertama di Dunia. pdf [5 Maret 2020]

Departemen Kehutanan - Sistem Informasi Legalitas Kayu (SILK), n.d. "Apa dan Bagaimana SVLK” [daring]. dalam https:// silk.menlhk.go.id/index.php/info/vsvlk/3 [Diakses 7 Maret 2020].

EU FLEGT Facility, 2011. "Kesepakatan Kemitraan Sukarela FLEGT antara Indonesia dan Uni Eropa" [daring]. dalam http://www.euflegt.efi.int/documents/10180/23029/Kes epakatan+Kemitraan+Sukarela+FLEGT+antara+Indone $\underline{\text { sia+dan+Uni+Eropa+-+Informasi+Ringkas+Mei+2011/1 }}$ cc9e1e7-659e-45e8-938c-c4751a3fd27d [Diakses 6 Maret 2020].

EU FLEGT Facility, t.t. "What is the Action Plan" [daring]. dalam http://www.euflegt.efi.int/flegt-actionplan\#: : text=The\%20EU\%2oFLEGT\%20Action\%20 Plan \% 20sets\%20out\% 20seven $\% 20$ measures \% 20 that,timber\%20from\%2oresponsibly\%20managed\%20 forests [Diakses 1 Juni 2020].

The Jakarta Post, 2016a. "Vietnam, EU agree on timber export regulations", The Jakarta Post, 14 Maret, [daring]. dalam https://www.thejakartapost.com/seasia/2016/04/14/ vietnam-eu-agree-on-timber-export-regulations.html [Diakses 5 Juni 2020].

The Jakarta Post, 2016b. "Plywood exports seen rising by 20\% in 2017", The Jakarta Post, 16 November, [daring]. dalam: https://www.thejakartapost.com/news/2016/11/16/ plywood-exports-seen-rising-20-2017.html [Diakses 5 Juni 2020]. 